\title{
C.
}

\section{Predation by a Cuban Racer, Cubophis cantherigerus pepei (Squamata: Dipsadidae) on an Endemic Cuban Green Woodpecker, Xiphidiopicus percussus percussus (Piciformes: Picidae)}

Tomás M. Rodríguez-Cabrera

Sociedad Cubana de Zoología, 10 de Octubre, La Habana 10700, Cuba (tomasmichel.rodriguez@gmail.com)

$\mathrm{T}$

The Cuban Racer, Cubophis cantherigerus (Dipsadidae; Fig. 1 ) is among the most versatile species of snakes in Cuba. It is widely distributed across the Archipelago and occupies a great variety of habitats ranging in elevation from sea level to 1,800 m (Henderson and Powell 2009; Rodríguez et al. 2010, 2013; Estrada 2012). The diet of this diurnally active forager includes crabs (unidentified), frogs (Eleutherodactylus, Osteopilus), lizards (Anolis, Cyclura, Diploglossus, Leiocephalus, Pholidoscelis), other snakes (Caraiba, Tropidophis), hatchling turtles (Eretmochelys), passerine birds (Turdus), doves (Columbina), domestic fowl
(Gallus), introduced murid rodents (Mus, Rattus), and bats (Phyllonycteris, for reviews see Henderson and Sajdak 1996; Henderson and Powell 2009; Reyes et al. 2013). Birds in particular might be consumed more frequently than reported. Reyes et al. (2013) presented evidence of predation on nestlings by Cuban Racers gathered during long-term research at a locality in southern Santiago de Cuba Province.

In the West Indies, woodpeckers have been reported as predators of a variety of amphibians and reptiles (see Henderson and Powell 2009 for a review), but as far as I

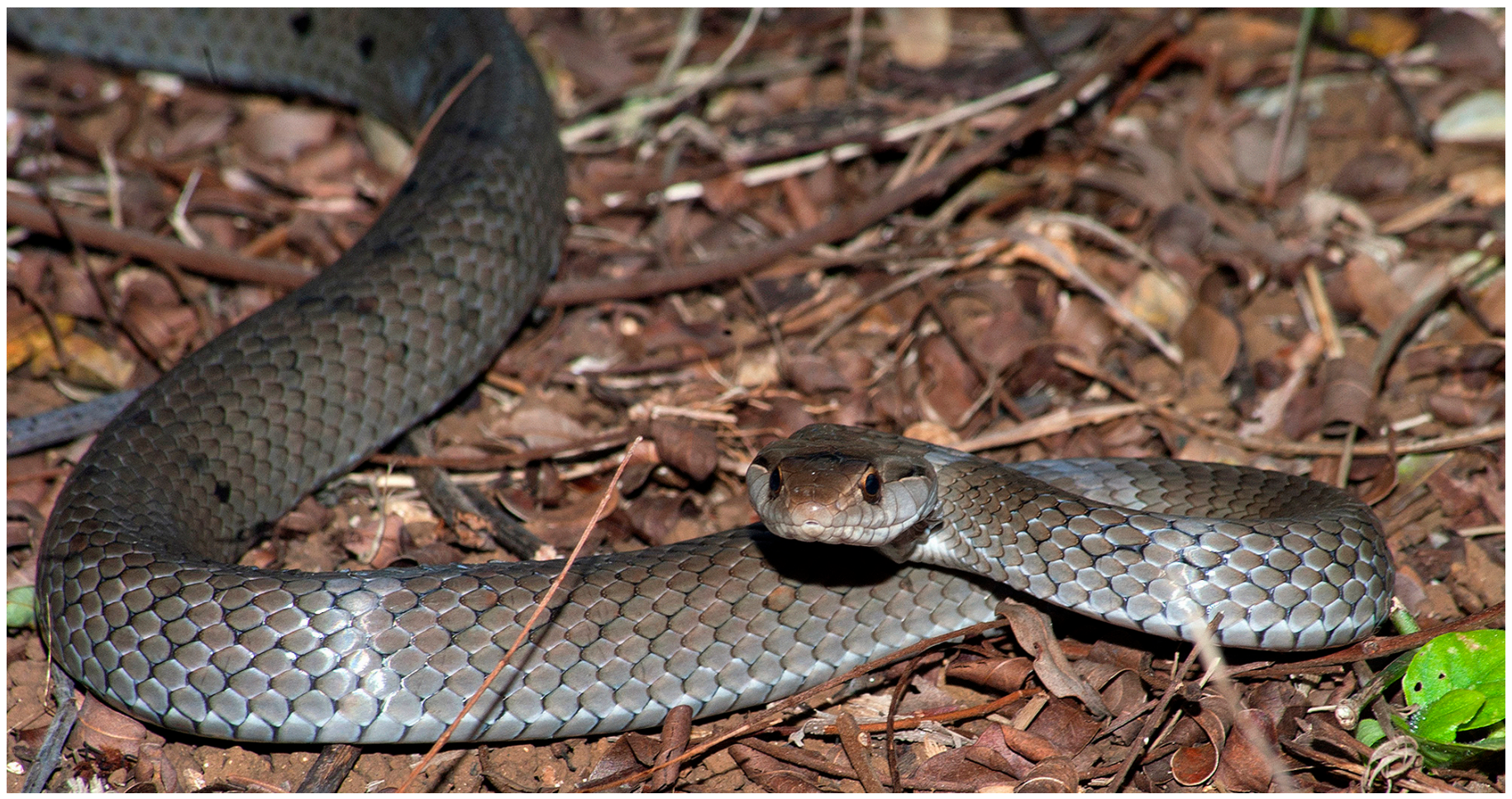

Fig. 1. Adult Cuban Racer (Cubophis cantherigerus cantherigerus) from the National Botanical Garden of Cuba, Havana. Photograph (C) Raimundo López-Silvero. 

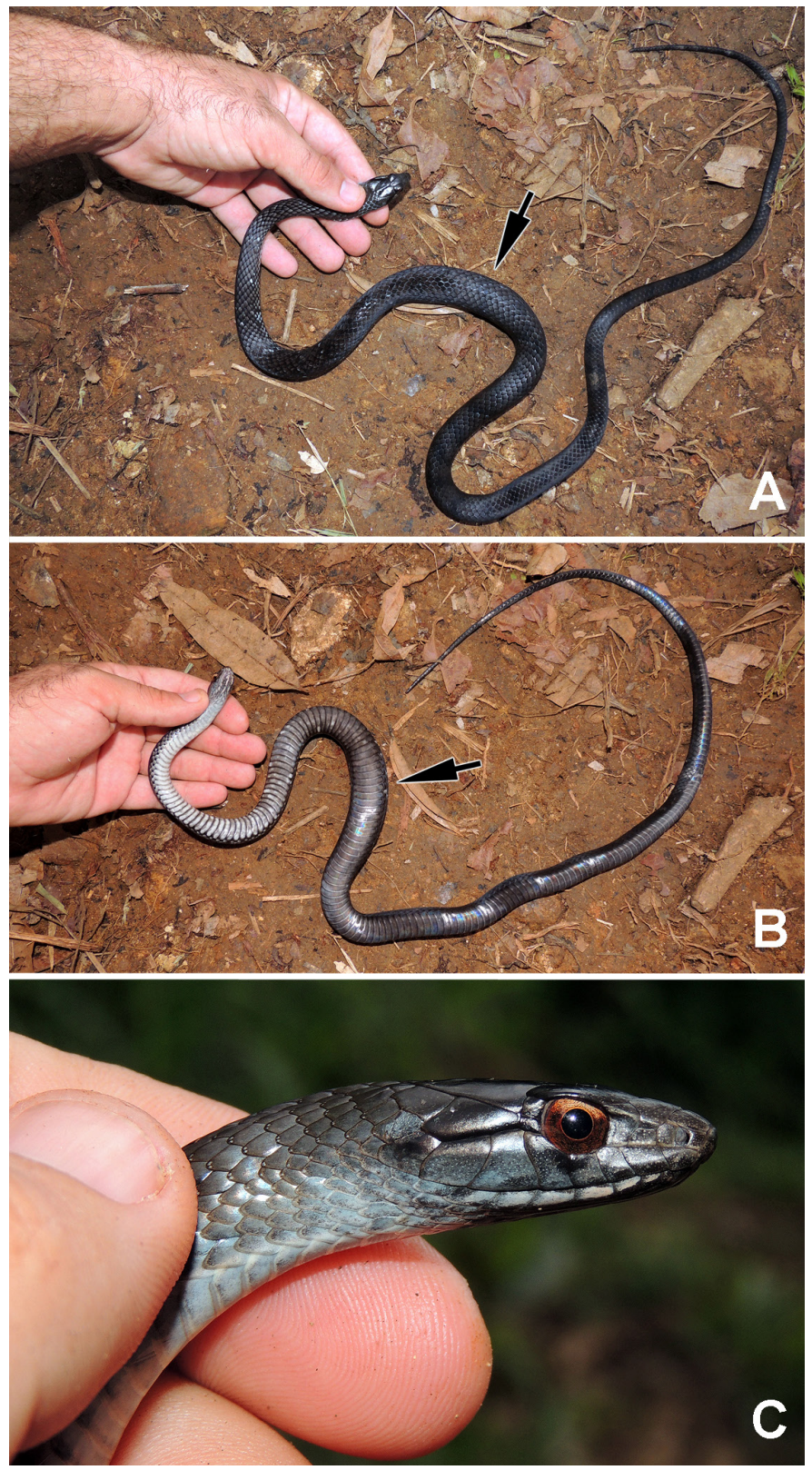

Fig. 2. A Cuban Racer (Cubophis cantherigerus pepei) collected at El Yunque, Baracoa, Guantánamo: dorsal (A) and ventral (B) views and details of the head (C). Note the bulge at midbody (arrows) indicating what was later revealed to be a hatchling Cuban Green Woodpecker (Xiphidiopicus percussus percussus). Photographs (C) T.M. Rodríguez-Cabrera.

know never as their prey. Interestingly, predation by snakes (e.g., Chilabothrus) on cavity-nesting birds, particularly on parrots in the genus Amazona (Wiley 1981; Snyder et al. 1987; Koenig 2001; Koenig et al. 2007), has been documented and/or suggested repeatedly in the region, but no comparable reports document predation on woodpeckers. del Hoyo et al. (2002) cited diurnal raptors (Accipiter, Buteo) and some toucans (Pteroglossus) as the only confirmed predators of adult and juvenile woodpeckers and their eggs outside the nest-hole or roost-hole, although they listed additional potential predators including snakes, squirrels, martens, and other birds, including other species of woodpecker. This apparent lack of reptilian predators could be attributable to the aggressive behavior and territoriality of woodpeckers against intruders during the breeding season (Kirkconnell et al. 1989; del Hoyo et al. 2002), and the reality that their strong bills are capable of inflicting enough damage to deter most predators. Nonetheless, herein I report an instance of predation by a Cuban Racer on a nestling Cuban Green Woodpecker, Xiphidiopicus percussus percussus (Piciformes: Picidae).

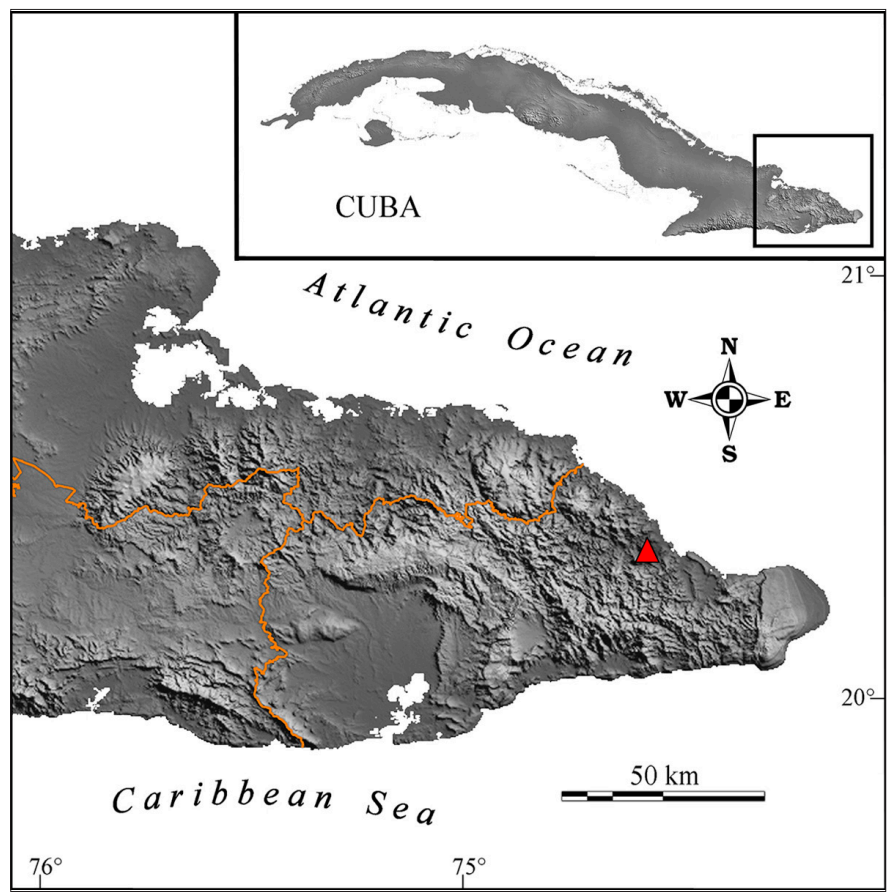

Fig. 3. Map of eastern Cuba depicting the location (red triangle) of El Yunque, Baracoa, Guantánamo Province, where we found a Cuban Racer (Cubophis cantherigerus pepei) with a hatchling Cuban Green Woodpecker (Xiphidiopicus percussus percussus) in its stomach.

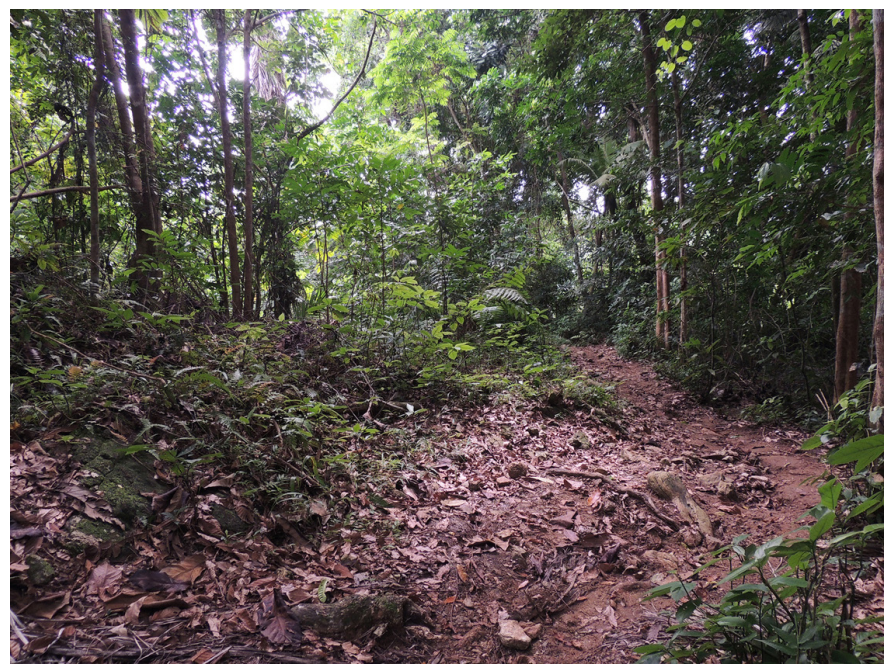

Fig. 4. Path to the summit of El Yunque and surrounding habitat (rainforest on limestone) at the location where we found a basking Cuban Racer (Cubophis cantherigerus pepei) with a hatchling Cuban Green Woodpecker (Xiphidiopicus percussus percussus) in its stomach. Photograph (C) T.M. Rodríguez-Cabrera. 

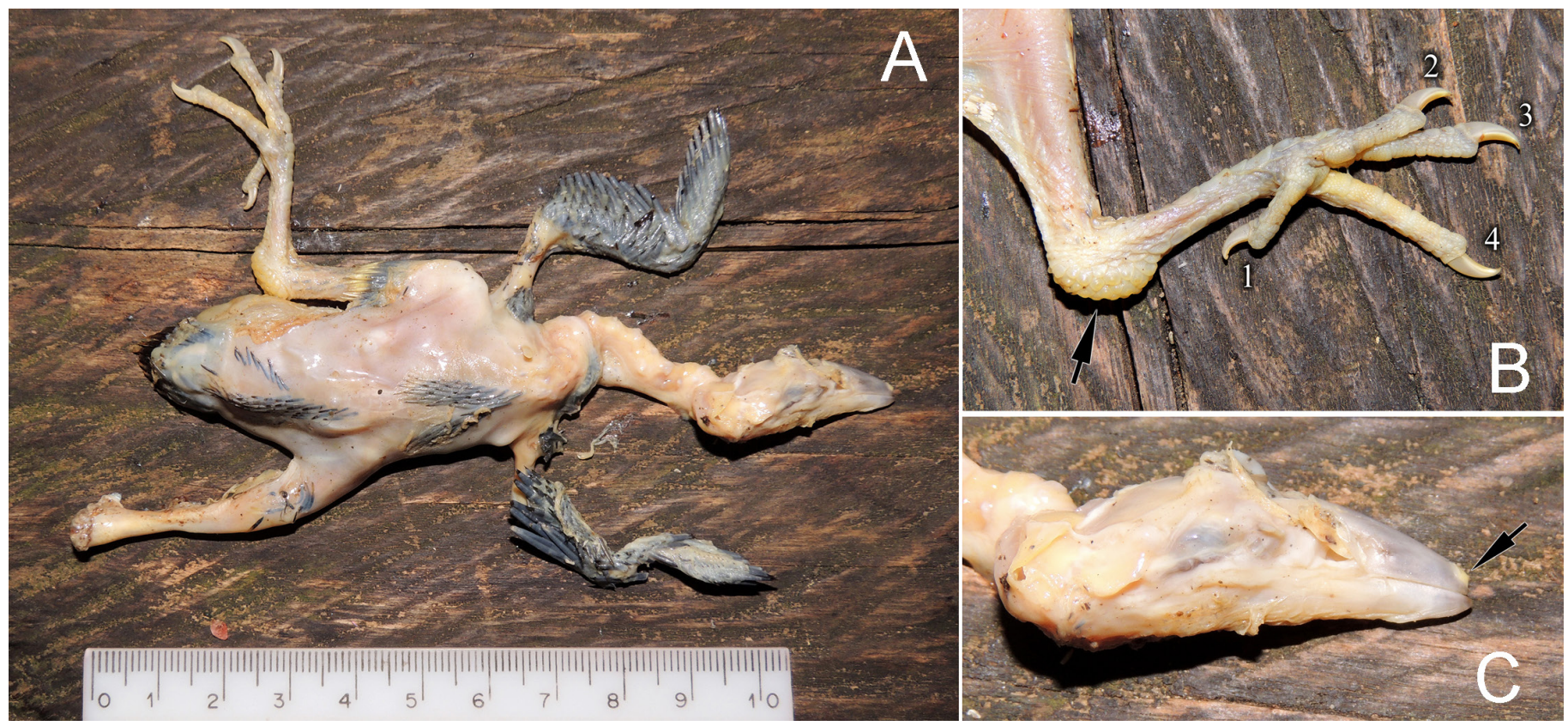

Fig. 5. The hatchling Cuban Green Woodpecker (Xiphidiopicus percussus percussus) regurgitated by a Cuban Racer (Cubophis cantherigerus pepei) from El Yunque, Baracoa, Guantánamo Province (A); with a detail of the foot showing the zygodactyl arrangement (toe numbers), the wart-like swelling at the "heel" of the tarsus (arrow), and the pale olive-green coloration of tarsal scales (B); and the strong bill with an egg tooth (arrow; C). Photographs @ T.M. Rodríguez-Cabrera.

At about 1500 h on 8 June 2015, I captured a Cuban Racer (400 mm SVL; Fig. 2) basking in a patchy forest light midway up the path to El Yunque $\left(20^{\circ} 20^{\prime} 40\right.$ ” $\mathrm{N}$, -74³3’56”W, WGS 84; 300 m asl), Baracoa, Guantánamo Province, Cuba (Figs. 3 and 4). The snake had a bulge at midbody suggestive of a recent meal (Figs. 2B-C). Induced regurgitation revealed a naked, partially digested hatchling (ca. $120 \mathrm{~mm}$ long; Fig. 5). The zygodactyl foot arrangement, the yellowish coloration of feather germs on the ventral and femoral pterylae, and the pale olive-green coloration of tarsal scales corresponded to a Cuban Green Woodpecker (Figs. 5 and 6). Also, the overall size of the chick, the developmental stage of plumage, the presence of a wart-like swelling at the "heel" of the tarsus (which is shed in the early phase of nestling's development; see del Hoyo et al. 2002 for a review), and the presence of an egg tooth suggested that it was only a few days old (Fig. 5). Furthermore, I repeatedly observed adults and fledglings of this species in the area during two consecutive days of the expedition. Due to the relatively fast metabolic rate of the Cuban Racer and the digestion stage of the chick, I presumed it had been taken no more than one or two days before its collection.

The population of Cuban Racers from the northern coast of eastern Cuba is considered a distinct subspecies, C. $c$.
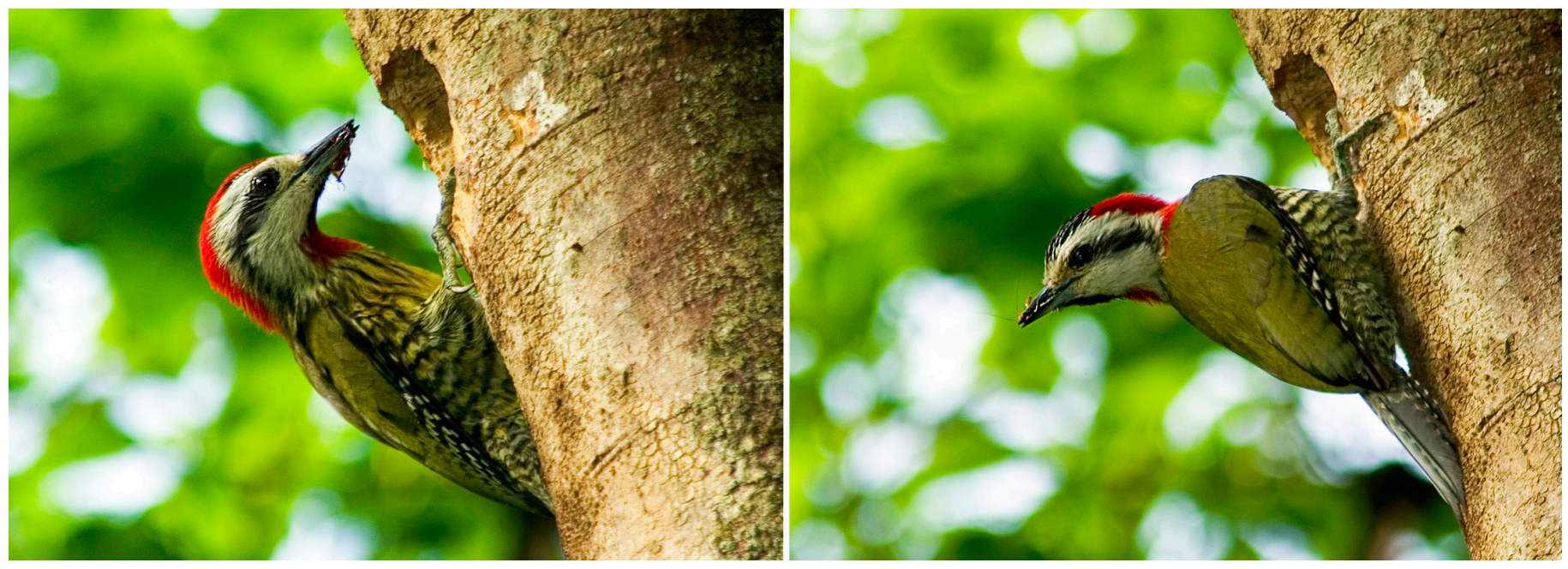

Fig. 6. Adult male (left) and female (right) Cuban Green Woodpeckers (Xiphidiopicus percussus percussus) carrying food to the nest. Photograph (C) Raimundo López-Silvero. 
pepei, characterized mainly by its dark dorsal coloration and bicolored venter (Schwartz and Thomas 1960; Schwartz and Henderson 1991). This matches the individual found at El Yunque (Fig. 2), thus providing the first report on the feeding habits of this subspecies.

The Cuban Green Woodpecker (Fig. 6) is a relatively small (210-250 $\mathrm{mm}$ ) species belonging to a monotypic genus (Xiphidiopicus) endemic to Cuba (Cruz 1974; del Hoyo et al. 2002; Raffaele et al. 2003; Garrido and Kirkconnell 2011). Despite its wide distribution and abundance throughout the Archipelago, its natural history is poorly known (Gundlach 1876; Walckinshaw 1953; Berovides et al. 1982; Alayón et al. 1986; Kirkconnell et al. 1989; Posada and Kirkconnell 1993; Denis et al. 1999). Indeed, no natural predators had previously been reported for this bird. The case presented herein not only represents the first record of woodpeckers in the diet of the Cuban Racer and the first natural enemy reported for the Cuban Green Woodpecker, but also the first record of snakes preying on woodpeckers in the West Indies. This also is further evidence of predation by the Cuban Racer on bird nests (see Reyes et al. 2013). Indeed, this snake has been observed preying on eggs of the Cuban Parakeet, Psittacara euops (Psittaciformes: Psittacidae), in artificial nests at the Ecological Reserve "Lomas de Banao" in the Guamuhaya Massif of central Cuba (M. Cañizares, pers. comm. 27.I.2017). I hope this report alerts wildlife conservation authorities in Cuba to the importance of safeguarding the nests of endemic cavity-nesting birds, which also include Fernandina's Flicker (Colaptes fernandinae; Piciformes), the Cuban Trogon (Priotelus temnurus, Trogoniformes), the Bare-legged Owl (Margarobyas lawrencii; Strigiformes), and the Cuban Pygmy-Owl (Glaucidium siju; Strigiformes) from relatively large climbing snakes such as the Cuban Racer and probably also the Cuban Boa (Chilabothrus angulifer, Boidae).

\section{Acknowledgments}

I thank Ansel Fong, Rolando Teruel, and Ramón Cueto (BIOECO, Santiago de Cuba) for their valuable assistance in the field and for logistical support during the expedition to Baracoa in June 2015. I also thank Maikel Cañizares for sharing unpublished data. Javier Torres, A. Fong, and M. Cañizares kindly provided literature references. Finally, I thank Raimundo López-Silvero for allowing the use of his photographs.

\section{Literature Cited}

Alayón, G., A. Kirkconnell, A. Llanes, and R.M. Posada. 1986. Observaciones conductuales en un nido del Carpintero Verde (Xiphidiopicus percussus percussus
Temminck; Aves: Piciformes: Picidae), p. 139. In: Resúmenes de la Quinta Conferencia Cientifica sobre Ciencias Naturales y Biologia. Universidad de La Habana, La Habana.

Berovides, V., H.J. González, and M.E. Ibarra. 1982. Evaluación ecológica de las comunidades de aves del área protegida de Najasa (Camagüey). Poeyana 239: $1-14$.

Cruz, A. 1974. Distribution, probable evolution, and fossil record of West Indian woodpeckers (family Picidae). Caribbean Journal of Science 14: 183-188.

del Hoyo, J., A. Elliott, and J. Sargatal (eds.). 2002. Handbook of the Birds of the World. Volume 7. Jacamars to Woodpeckers. Lynx Editions, Barcelona.

Denis, D., L. Torrella, A. Jiménez, and K. Beovides. 1999. Observación de Carpinteros Verdes (Xiphidiopicus percussus) depredando huevos de garzas (Aves: Ardeidae). El Pitirre 12: 95.

Estrada, A.R. 2012. The Cuban Archipelago, pp. 113-125. In: R. Powell and R.W. Henderson (eds.), Island lists of West Indian amphibians and reptiles. Bulletin of the Florida Museum of Natural History 51: 85-166.

Garrido, O.H. and A. Kirkconnell. 2011. Aves de Cuba. Spanish Edition. Cornell University Press, Ithaca, New York.

Gundlach, J. 1876. Contribución a la ornitología cubana. Imprenta La Antilla, La Habana.

Henderson, R.W. and R. Powell. 2009. Natural History of West Indian Amphibians and Reptiles. University Press of Florida, Gainesville.

Henderson, R.W. and R.A. Sajdak. 1996. Diets of West Indian racers (Colubridae: Alsophis): Composition and biogeographic implications, pp. 227-338. In: R. Powell and R.W. Henderson (eds.), Contributions to West Indian Herpetology: A Tribute to Albert Schwartz. Contributions to Herpetology, volume 12. Society for the Study of Amphibians and Reptiles, Ithaca, New York.

Kirkconnell, A., G. Alayón, R.M. Posada, and A. Llanes. 1989. Observaciones conductuales en dos nidos de Xiphidiopicus percussus percussus (Aves: Piciformes: Picidae). Poeyana 371: 1-18.

Koenig, S.E. 2001. The breeding biology of Black-billed Parrot Amazona agilis and Yellow-billed Parrot Amazona collaria in Cockpit Country, Jamaica. Bird Conservation International 11: 205-225.

Koenig, S.E., J.M. Wunderle, Jr., and E.C. Enkerlin-Hoeflich. 2007. Vines and canopy contact: A route for snake predation on parrot nests. Bird Conservation International 17: 79-91.

Posada, R.M. and A. Kirkconnell. 1993. Aspectos sobre la historia natural del Carpintero Verde (Xiphidiopicus percussus). Pitirre 6: 8 (abstract).

Raffaele, H., J. Wiley, O. Garrido, A. Keith, and J. Raffaele. 2003. Birds of the West Indies. Princeton University Press, Princeton, New Jersey.

Reyes Vázquez, A.E., Y. Segovia Vega, and A. Fong G. 2013. Predation on birds by the Cuban Racer Cubophis cantherigerus (Squamata: Dipsadidae) in Cuba. Herpetology Notes 6: 165-166.

Rodríguez Schettino, L., V. Rivalta González, and E. Pérez Rodríguez. 2010. Distribución regional y altitudinal de los reptiles de Cuba. Poeyana 498: 11-20.

Rodríguez Schettino, L., C.A. Mancina, and V. Rivalta González. 2013. Reptiles of Cuba: Checklist and geographic distribution. Smithsonian Herpetological Information Service 144: 1-96.

Schwartz, A. and R.W. Henderson. 1991. Amphibians and Reptiles of the West Indies: Descriptions, Distributions, and Natural History. University of Florida Press, Gainesville.

Schwartz, A. and R. Thomas. 1960. Four new snakes (Tropidophis, Dromicus, Alsophis) from the Isla de Pinos and Cuba. Herpetologica 16: 73-90.

Snyder, N.F.R., J.W. Wiley, and C.B. Kepler. 1987. The Parrots of Luquillo: Natural History and Conservation of the Puerto Rican Parrot. Western Foundation of Vertebrate Zoology, Los Angeles, California.

Walckinshaw, L.H. 1953. Some bird observations on the Isle of Pines. Papers of the Michigan Academy of Science Arts and Letters 38: 261-268.

Wiley, J.W. 1981. The Puerto Rican Amazon (Amazona vittata): Its decline and program for its conservation, pp. 133-160. In: R.F. Pasquier (ed.), Conservation of New World Parrots. International Council for Bird Preservation Technical Publication No. 1. Smithsonian Institution Press, Washington, D.C. 